\title{
Industry Structure in Developing Company's Long-Term Business Strategy
}

\author{
Vesna Sesar \\ University North, Croatia \\ Krešimir Buntak \\ University North, Croatia \\ Ivana Martinčević \\ University North, Croatia \\ Saša Bogović \\ Phoenix pharmacia, Croatia
}

\section{Abstract}

Strategic controlling has become an imperative in business planning and determining company's long-term goals. Companies use different managerial tools in their planning process in order to determine possible threats and opportunities in their business environment. The goal of the paper is to present a case study of one pharmaceutical Croatian company using the model INDUSTRUCT, which is utilized for analysing industrial environment, which is, develop based on the Porter's five forces model. Although recent research results show that companies in Croatia use more often operational tools in their business rather than strategic tools this model shows the simplicity of its use and easiness of analyse. Focus of the research is highly competitive rivalry in pharmaceutical industry characterized with the big threats from supplier, buyers, substitutes, as well as newcomers. In such highly competitive industry, companies must constantly rethink their strategies and use tools that will help them detect threats and opportunities hiding in their environment.

Keywords: management strategy, INDUSTRUCT, Porter's five forces, controlling JEL classification: M21, M49, L10

\section{Introduction}

Strategic controlling is a future oriented practice and a pillar for management decisions. Studies in Croatia show that many organizations still think that controlling has to deal mainly with operational tasks, since the use of strategic instruments is fewer than the use of operational tools (Osmanagic Bedenik, 2017; Meter et al., 2017). This means that companies are more oriented on achieving short-term goals. On the other hand, environment changes demand modern techniques that companies should use in detecting opportunities or threats.

Therefore, the importance of strategic controlling arises as a resolution to questions like where to, with what, how and when to produce or serve on the markets in the future. The research on Australian manufacturing firms done by Chenhall et al. (1998) show application of modern management accounting practice. Industry structure analysis represents an important source of information's for such changes in the industry. Analysing industry structure has been a major area of interest both for practice and academic world from the begging works of Demsetz (1973) and Mancke (1974) to the most significant contribution from professor Porter with its definition of industry constructs which influence long-term 
competition in an industry (Porter, 1979). Porter in his work proved that company performance depends on five forces and not on luck or greater or lesser company efficiency (Porter, 1979). Hence, this model has its great value for controllers in terms of gathering information's that are needed for creating business strategy.

Research aim is to show results of a simple instrument used in determining competition within highly competitive pharmaceutical industry. Companies have to be aware of the treats and opportunities in their environment to be able to respond to these treats or to seize opportunities.

\section{The significance of controlling in making efficient and effective decisions}

Controlling has many definitions. As Očko et al. (2009: 40) state controllers are "wizards of the new age" then controlling can be described as the "magical hat of the wizard" with variety of possibilities in assuring companies' efficiency and effectiveness. Its development in Croatia started in the 90's. This development brought a lot of confusion about what is controlling and what are main activities since its development started. According to the research of Grisar et al. (2016) controlling in Austria, Germany and Switzerland is known as management accounting and management control system (Grisar et al., 2016). Since its infancy, almost two decades past and its development is getting deserved attention in business and academic circles. Coppo states that controlling "contributes to a strategic perspective by helping managers to understand where and how to react to situations" (Sambonet, 2010, p. 729). It can be defined as a function that brings to a transparency of achieving organizational goals.

Every organization sets its operational and strategic goals. Operational goals are short-term goals and the role of controlling is in analysing all company's resources in order to derive their optimal efficiency. Strategic goals are long-term goals and they are oriented toward the future. The role of strategic controlling is in anticipating future events and finding areas for business growth. Except operational and strategic controlling there is also a normative controlling which is oriented toward internal organizational standards and business policies. According to Osmanagić Bedenik (2017, p. 26) in managing business "there is a need to balance operational, strategic and normative business perspective into so called integrated controlling".

Controlling uses many instruments in analysing and resolving problems. The appropriate set of instruments depends on the market and company's characteristics. According to the research done by Osmanagić Bedenik (2017) there is a significant use of operational instruments in Croatian organizations while strategic ones are less used. That means that Croatian companies are more internal oriented, coping with current problems in order to achieve short-term goals while strategic instruments are still less used in business practice. As Očko et al. state (2009, p. 19) Croatian companies have certain characteristics that can anticipate slow adaptation to new environment situations or slow response to competitive rivalry. Those characteristics are: "manager is in most cases also the owner of a company, centralized management, autocratic decision style, no formal organizational structures, poor or no HR management, lack of good communication, traditionally oriented accounting department, reports that rely only on tax regulations, outdated informational system, lack of continuous employee's education" (Očko et al., 2009, p. 19). It is clear that such organizational characteristics in today's business can lead to slow adaptation to new environment situations or slow response to competitive rivalry. 
Company that is able to respond quickly to competitive moves on the market is more adaptive then others. If it is able to adapt sooner than others, then consequently loses less money than their competitors. Gleißner et al. (2013) state that knowledge about company's competitive advantage and a clear picture of the target market are crucial for long-term planning and efficient control of defined goals. Hutzschenreuter (2010) indicates that strategic moves are possible when you think outside the box and reacts fast.

\section{Industry structure and measurement models}

Industry analysis, as an important part of strategic analysis, should help predict the average level of long-term profitability of the industry and understand the strategic differences between industrial competitors. The analysis of the company's competitive position and performance is primarily based on an analysis of the industry within which the company carries out its business. Since the industries are significantly different, knowledge of the distinctive economic features of the industry is the basis for analysis and foreseeable strategic strides in the industry. Utterback et al. (1993) state that in a market where competition is high will result in shortening the period of technological change and such competitiveness would attract new entrants. Sampler (1998) introduced information separability and information specificity in analysing industry structure since in the 90s the Internet has brought major shift in analysing information's and competitive rivalry. Nohria et al. explain (1991) that industry structure consists of strategic groups where organizations compete with similar capabilities and since they have similar environments they'll respond similar to environment changes because those changes are significant to every organization in the specific market. Further, Christmann et al. (1999, p. 243) state that industrial structure view lies in "identifying structural characteristics of industries, such as the degree of rivalry between firms within the industry, that affect the performance of firms within the industry and lead to differential performance between industries". Also, Karabag et al. (2014) state that industry structure, business group membership, strategy and state support determine organizational business performance in emerging economies.

The most recognizable model for analyzing industry structure is universally known Porter's model of five competitive forces (Porter, 1979). The model is developed with the assumption that long-term profitability of industry as well as companies within the industry depends on the influence of the following five factors (competitive forces): 1. Competitiveness within the observed industry (strength of competitiveness within the industry), 2. Threat of new entrants (pressures of potential new competitors) 3. Threat of Substitutes (Customer Switching to Replacement Products), 4. Negotiating Power of Customers, 5. Negotiating Power of the Suppliers. Five competitive forces as opportunities and threats are reflected in the observed company: 1. Competitiveness within the observed industry - the competitive strength within the industry is an important factor of industrial profitability. Discretion among competitors can be "brutal" (price war and various aggressive tactics), "middle or very common" (allowing most industry members to earn profitable profits) and "poor" (seldom trying to reward customers, has a lot of appealing earnings) (Thompson et al., 2008). 2. Threat of new entrants - Companies $s$ that may be interested in competing with the same or similar assortment. 3. Threat of Substitutes - the existence of substantive products directly limits the defective industry and affects its profit potential. The existence of substitute products means the ability for consumers to satisfy their needs in another way. Negative effects of strong substituents exist as long as the cross-price elasticity of demand is high and the industry therefore has fewer profits and will not 
be able to develop on desired way. 4. Negotiating power of customers - customer power is defined by their ability to influence decision-making variables in their suppliers' strategies (pressure on price reductions, demand for higher quality and the same price). 5. Negotiating Power of Suppliers - Suppliers show negotiating power over companies in the industry by lowering their profitability by increasing the price of their assortment, reducing product quality at the same price. Porter $(1980,1985)$ points out that industry companies need to improve their starter position by finding the most-matched suppliers and customers who have the least power.

The value of this model is unquestionable because its broad application and focus on the analysis of competitive relationships within the industry and in that way ensures companies to define and build a business strategy and to ensure its market competitiveness.

However, Grundy (2006) mentions some limitations of the model such as:" overstressing macro analysis, oversimplifies industry value chains, it fails to link directly to possible management action, encourages the mind-set of an 'industry' as a specific entity with ongoing boundaries, appears to be self-contained, It is couched in economic terminology" (Grundy, 2006 p. 215). Hence, Lee et al. (2012) emphasize that the model is hard to operationalize and presents an ANP model.

Pecotich et al. (1999, p. 409)) argues that "there is no psychometrically validated measurement scale that is consistent with the theory" so he developed an instrument INDUSTRUCT which gave validation of Porter's five forces and measures for industry structure which were inconsistent. The main purpose was to create instrument with psychometric characteristics that is simple to use, and easy to evaluate. In the first step the authors primarily detected 126 variables to measure Porter's forces. At the end, those 126 variables where reduced to 55 items and then 42 items. The authors constructed the instrument so that each force had minimum 10 items. The original instrument was tested on 151 managers in Australian companies. For the purpose of a research done in 2004 on 150 SME Croatian companies this model was adjusted. So the number of items for determining forces was increased to 52 items (Pecotich et al. 2004; Meter et al., 2017). This instrument was taken into consideration when doing this case study.

\section{Methodology and Results}

For the purpose of this case study the adjusted instrument INDUSTRUCT was taken, since its validation was confirmed in the research done by Pecotich et al. (2004) in Croatian environment context.

Case study was done on Phoenix Pharmacia company; which can be classified as a big-sized company in Croatia. The company is a member of Phoenix Group which operates in 26 countries in Europe. It is obvious that company operates in a highly complex environment. The questionnaire with 52 items was distributed to a controlling team with director of controlling ahead. Each question they analysed together and decided on a 5 point Likert scale 11 "completely disagree and 5 completely agree) about the significance of certain question in the context of their market position. Based on their answers, arithmetic mean was calculated for every threat.

The results are shown in Figure 1. Analysed data show an intense rivalry within industry. Competitors are described as harsh and combative. While lowering prices in such intense industry is expected as a move against competitor's prices. Items regarding high exit barriers, excess capacity of an industry, similarity of products and short period of use are rated with 2 points on the Likert scale as "I disagree". Negotiation power of customers has the biggest 3,8 points on the Likert scale and in 
this industry customers are well informed about product demand and their prices and they are aware of industry profitability and cost structure. They also unite in order to gain negotiation power. Also, they can easily change suppliers since cost of change is low. Customers don't have the possibility of entrance integration in the industry. The intensity of competition between customers in the industry and customers buying industry products from many suppliers is rated 3 points on the Likert scale, meaning "I don't agree nor disagree". Negotiation power of suppliers is rated 3,2 on the Likert scale where their products are differentiated and represent an important input for this industry. Also there is a small number of suppliers who have a large share in input supply and their products can affect final quality of products within the industry. Overall the power of suppliers or group or suppliers is rated as powerful. Threat of substitute products has 3,4 points on the Likert scale. This result shows that there are a large number of substitutes, products within industry can easily be replaced with many other products, substitutes for the products are produced in high-profit industries and there is a great pressure on cheaper substitutes (substitute products). The last force is the threat of newcomers. It's rated with average 2,8 on a Likert scale. Here if the rate on on the Likert scale is higher means that threat of newcomers is smaller and vice versa.

Therefore, based on the results, threat of newcomers can be described as medium. Newcomers don't have to invest a large amount of capital into risky and irreversible advertising costs and / or research and development. There are no barriers in inserting products of newcomers into existing distribution channels. However, state policy and regulations make newcomers harder to enter the industry. Also newcomers require significant capital and / or financial resources to enter the industry and they have to spend considerable amount of money to build their own brands and get customers that are loyal to existing brands.

Figure 1

Perception About Competition Within Industry

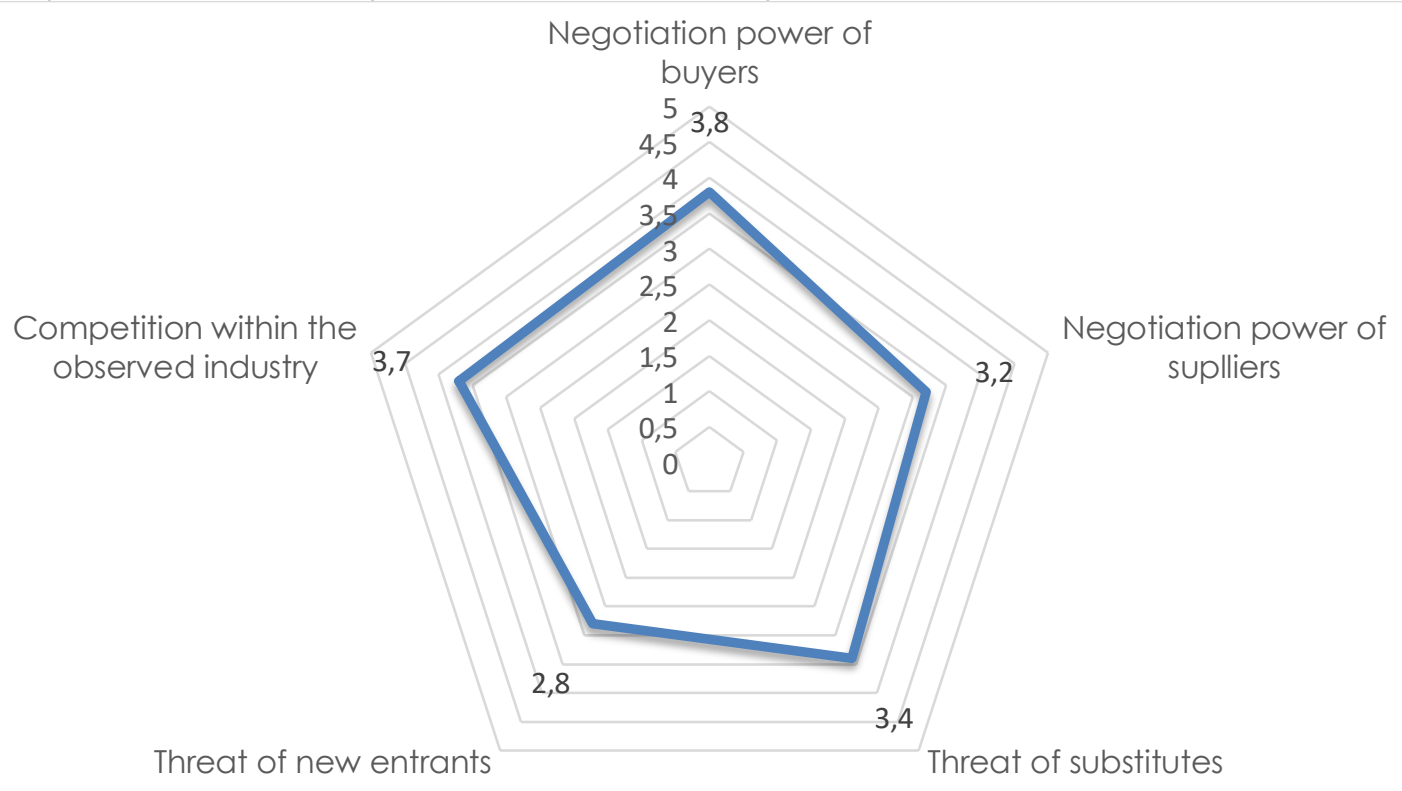

Source: Authors' illustration 


\section{Conclusion}

The paper presented industry analysis on one big-size company operating in pharmaceutical industry was done. In the case, an instrument INDUSTRUCT was used for determining the power of five forces. The results show an overall picture of the industry as a highly competitive with high profits and great customer and supplier power, with medium threat of newcomers. This instrument is used in strategic controlling to analyse industry in terms of the above mentioned forces to help companies be up to date of the threats and opportunities which they have to address.

To be able to make a complete analysis of the environment and gather information's that will be useful for determining strategic goals and direction of the company in the future, controlling combines many other tools. In order to optimize all information's outside and inside the company, other tools should be used such as PESTLE analysis to gather information's about political, economic, social, technological, legal and environmental features. Also, company has to analyse all resources that has or should have in the future to stay competitive. In internal analysis, tools like VRIO method or portfolio analysis should be used to see which resources represent pillars of the company and which are perceived as weakness of the company.

Based on this comprehensive analysis of internal and external environment companies create strategies and business goals. Companies have various strategies to choose. Depending on the quality of information's gathered with useful tools in a context in which company operates (internal and external environment), managers should be able to choose the strategy that best suits a company in achieving the vision. This case gives a practical and theoretical contribution to the area of strategic controlling and shows its ease of use in practical and academic world.

\section{References}

1. Buble, M., Cingula, M., Dujanić, M., Dulčić, Ž., Gonan Božać, M., Galetić, L., Ljubić, F., Pfeifer, S., Tipurić, D. (2005), Strateški menadžment (Strategic Management), Sinergija, Zagreb

2. Chenhall, R. H., Langfield-Smith, K. (1998), "Adoption and benefits of management accounting practices: an Australian study". Management accounting research, Vol 9 No. 1, pp. 1-19.

3. Christmann, P., Day, D., Yip, G. S. (1999), "The relative influence of country conditions, industry structure, and business strategy on multinational corporation subsidiary performance", Journal of International Management, Vol. 5, No 4, pp. 241-265.

4. Demsetz, H. (1973), "Industry structure, market rivalry, and public policy", The Journal of Law and Economics, Vol. 16, No. 1, pp. 1-9.

5. Grisar, C., Meyer, M. (2016), „Use of simulation in controlling research: a systematic literature review for German-speaking countries", Management Review Quarterly, Vol. 66, No. 2, pp. 117-157.

6. Grundy, T. (2006), "Rethinking and reinventing Michael Porter's five forces model", Strategic Change, Vol. 15, No. 5, pp. 213-229.

7. Hutzschenreuter, T. (2010), "Mit strategischem Management durch die Krise" (With strategic management through the crisis), Controlling \& Management, Vol. 54, No. 1, pp. 32-33.

8. Karabag, S. F., Berggren, C. (2014), "Antecedents of firm performance in emerging economies: Business groups, strategy, industry structure, and state support", Journal of Business Research, Vol. 67, No. 10, pp. 2212-2223. 
9. Lee, H., Kim, M. S., Park, Y. (2012), "An analytic network process approach to operationalization of five forces model", Applied Mathematical Modelling, Vol. 36, No. 4, pp. 1783-1795.

10. Mancke, R. B. (1974), "Causes of interfirm profitability differences: a new interpretation of the evidence", The Quarterly Journal of Economics, Vol. 88, No 2, pp. 181-193.

11. Meter, M., Šarčević, M. (2017), "Primjena instrumenata kontrolinga u praksi hrvatskih poduzeća" (Application of controlling instruments in the practice of Croatian companies), Kontroling u praksi- Instrumenti kontrolinga, Poslovna učinkovitost d.o.o. za poslovno savjetovanje, Zagreb, pp. 7-20.

12. Nohria, N., Garcia-Pont, C. (1991), "Global strategic linkages and industry structure", Strategic management journal, Vol. 12, No. S1, pp. 105-124.

13. Očko, J., Švigir, A. (2009), Kontroling: upravljanje iz backstage (Controlling: backstage management), Alitus savjetovanje, Zagreb.

14. Osmanagić Bedenik, N. (2017), "Instrumenti integriranog i kriznog kontroling" (Instruments of integrated and crisis controlling), Kontroling $u$ praksi- Instrumenti kontrolinga, Poslovna učinkovitost d.o.o. za poslovno savjetovanje, Zagreb, pp. 21-36.

15. Pecotich, A., Hattie, J., \& Low, L. P. (1999), "Development of industruct: A scale for the measurement of perceptions of industry structure", Marketing Letters, Vol. 10, No. 4, pp. 403-416.

16. Pecotich, A., Renko, N., Pavicic, J. (2004), "Reinterpretation of industruct and me porter's five forces model: empirical evidence from croatian business practice", in proceedings of International Conference "An Enterprise Odyssey", University of Zagreb, Faculty of Economics and Business, p. 1823.

17. Porter, M. E. (1980), Competitive Strategy: Techniques for Analyzing Industries and Competitors, Free Press, New York, NY, USA.

18. Porter, M. E. (1985), Competitive Advantage: reating and sustaining superior performance, Free Press, New York, NY, USA.

19. Porter, M. E. (1979), "How competitive forces shape strategy", Harvard business review Vol. 57, No. 2, pp.137-145.

20. Gleißner, W., Helm, R., Kreiter, S. (2013), "Measurement of competitive advantages and market attractiveness for strategic controlling", Journal of Management Control, Vol. 24, No. 1, pp. 53-75.

21. Sambonet, D. B. (2010), "Controlling contributes a strategic perspective", Controlling and Management Review, Vol 54, No. 1, pp. 71-72.

22. Sampler, J. L. (1998), "Redefining industry structure for the information age", Strategic Management Journal, Vol. 19, No. 4, pp. 343-355.

23. Thompson, A. A., Strickland, A. J., Gamble, J. E., Saganić, P., Ostojčić, I., Žarković, D. (2008), Strateški menadžment: U potrazi za konkurentskom prednošću, Teorija i slučajevi iz prakse (Strategic Management: Looking for Competitive Advantage: Theory and Case Studies), Mate, Beograd.

24. Utterback, J. M., Suárez, F. F. (1993), "Innovation, competition, and industry structure", Research policy, Vol. 22, No. 1, pp. 1-21. 


\section{About the authors}

Vesna Sesar, univ.spec.oec., MBA, finished the Faculty of Economics, University of Zagreb. Continued postgraduate studies in "Business Management"; at the Faculty of Economics in Zagreb and acquired the title univ.spec.oec., MBA, 2014. She entered International Joint Cross-Border PhD Programme at University North. Through previous work experiences she has acquired competence in the area of financial analysis and in accounting. Today she works as a Lecturer at University North in the area of controlling, business management, microeconomics, the basic principles of economics, accounting, strategic management and business process management. The author can be contacted at vesna.sesar@unin.hr.

Krešimir Buntak is an Associate professor at University North. After finishing University of Engineering and Shipbuilding in Zagreb, he gained his PhD in economics. During his education, he worked over 20 years in management positions from the public and local governments, through the private sector to large export organizations in the automotive industry. Since 2004 he has taught on various national and international schools and colleges about managing, management, organization, business economics, BPM, quality management systems and business excellence. He is the author of more than 100 scientific and technical papers and one polytechnic textbook. The author can be contacted at kresimir.buntak@unin.hr.

Ivana Martinčević, Master of Economics, is a lecturer at the University North, Department of Business and Management and a PhD candidate at the University of Applied Sciences Burgenland in Eisenstadtu. She is the author and co-author of numerous domestic and international professional and scientific articles, and has participated in several international conferences. The author can be contacted at ivana.martincevic@unin.hr.

Saša Bogović finished a Medical School Varaždin, "Pharmaceutical Technician". Currently studying at University North, "Tehnical and Economic Logistics". He works at Phoenix farmacija. Previous work experience was Warehouse Manager, Logistic Controller and Internal Control. Through previous work experience he has acquired competence in the area of logistics and controlling. Today he works as a Sales Controller. The author can be contacted at s.bogovic@phoenix-farmacija.hr. 